\title{
IMPORTANCE OF KNOWLEDGE AND SKILLS OF PROJECT MANAGERS FOR IMPLEMENTATION OF TECHNICAL PROJECTS
}

\author{
Martina ONDROUCHOVÁ ${ }^{*}$, Pavel MÁCHAL ${ }^{1}$, Branislav GABLAS ${ }^{2}$ \\ ${ }^{1}$ Mendel University in Brno, Czech Republic \\ ${ }^{2}$ Pan-European University in Bratislava, Slovak Republic
}

\begin{abstract}
The level of technical knowledge and skills of project managers shows a high differentiation, which has an impact on the management of (non)investment projects in the given region, regardless of the sector area such as agriculture, entrepreneurship or services. This paper aims to confirm that the level of technical knowledge and skills of project managers is highly differentiated in the South Moravian Region of the Czech Republic and to identify the knowledge areas that are affected by the ignorance in this region the most. The research has shown that the management knowledge areas most affected by ignorance in the South Moravian Region of the Czech Republic are namely Scope management, Quality management and Communication management. These findings show a high level of differentiation in the knowledge and skills of project managers on the regional level, having direct impact on public and private projects in the given region. Due to this issue, there should be established certain standards for project management, which can be demanded by central authorities.
\end{abstract}

Keywords: project management; regional development; technical knowledge and skills; project managers

The projects of sustainable development cover a wide spectrum in regards to the length and geographical focus, including the local, regional and global level (Gareis et al., 2013). The organizations such as IPMA, PMI and ISO (IPMA, 2006; PMI, 2013; ISO, 2012) use various concepts for definition of projects. A research currently conducted has shown that there is a significant increase in the performance of project management methods and tools in organizations mainly due to globalization (Too and Weaver, 2013). Project management is a powerful instrument for accomplishing the planned purposes of organization's execution and control of activities in systematic order (Mir and Pinnington, 2014). It is applicable for any type of sector area - agriculture, services, social issues, etc. The project type determines how the project meets its stated goals. Private sector projects are usually required to provide some service or tangible goods in a reasonably profitable way. On the other hand, the public sector is more about to provide services on a non-profit basis with the aim to meet social development objectives and to ensure economic growth (Jó and Barry, 2008). That is the reason why there is a crucial importance of having qualified and professional workers in right working positions. Standards state that the project manager can contribute to project success by $34-47 \%$ (Frank, 2002). There are also multiple scientific sources dealing with project's critical success factors (Hyväri, 2006; Bannerman, 2008; Khang and Moe, 2008; Nunnenmacher, 2011; Khan and Spang, 2011).

There are several researches on how the projects can contribute to the process of elaborated creation of value and output (Thomas and Mullaly, 2007; Winter and
Szczepanek, 2008; Lechler and Cohen, 2009); however, there is a significantly lower amount of researches on the level of abilities and skills of project managers. The difference between the competencies defined by project management standards and the competencies required for considering of sustainability was observed by Silvius et al. (2012). Furthermore, there is a study which aims to specify the competence gap of project managers in regards to sustainability and to provide a guidance on how to remove this gap (Silvius and Schipper, 2014), as well as a research focused on specific improvements in the majority of the behavioural competencies of project managers or project management graduates (Alam et al., 2010). The analyses of knowledge areas based on literature review, as well as their summary, have already been presented by Hwang and $\mathrm{Ng}$ (2013). This paper utilizes several of them.

The core of projects management remains in a triple constraint - scope, budget and schedule (Cuellar, 2010; Van Wyngaard et al., 2012) despite the fact that there are attempts to break this concept (Barrata, 2006). The triple constraint is considered a framework for the purposes of this paper. Since different regions are dealing variously with their own issues of development (Rodríguez-Pose and Fratesi, 2004; Iyer et al., 2005; Storper, 2011), it has been observed that the level of knowledge and skills of project managers in the field of regional development are of a high differentiation, which is influencing the level of processing and project management. 


\section{Material and methods}

This paper is divided into three thematic sections - the first section provides a background of the importance of knowledge integration of project management in the regional development field; the second section explains the paper and survey methodology by focusing on the studied area and survey approach; and the third section discusses the survey findings with a brief conclusion.

\section{Study area}

The aim of this paper is to confirm that the level of knowledge and skills of project managers in the regional development field are of a high differentiation and to identify the knowledge areas which are the most affected by the ignorance in the municipalities of the II and III levels of South Moravian Region in the Czech Republic.

The paper accomplishes these aims through the analysis of two surveys. The survey on the level of knowledge and skills of project managers in regional development at the NUTS III level was published in the paper by Kopeckova and Machal (2016). The research was conducted in South Moravian Region in municipalities with authorized municipal office (II level) and with extended powers (III level). The specification of the municipalities' level is given to 34 municipalities of South Moravian Region by Implementary Regulation $388 / 2002$, and 65 project managers in total have undergone the survey. The structure of project managers given by sex, age and years of practice are indicated in Table 1.

\section{Survey approach}

The survey was conducted by means of structured questionnaires. Questionnaires were aimed at observing the level of knowledge and skills concerning fundamental principles, tools and techniques of project management according to the international standards of project management (IPMA, PMI). The survey was conducted through questionnaires and interviews with the relevant project managers employed at municipal offices in the municipalities of the II and III levels who were personally managing (non)investment projects in the given area. The questionnaire contained 42 questions divided into the fundamental knowledge areas of project management defined by the IPMA and PMI standards. There have been collected 65 questionnaires in total. Project managers at given municipalities were interviewed on expression of their knowledge and skills in 9 knowledge areas of project management. The given answers were proposed and scaled according to the following criteria.

The colours of answers in the table correspond to the colours of answers in the particular figures. The survey was conducted since March to June 2016.

Statistical dispersion is utilized for the statistical analysis purposes. Statistical dispersion measures how far a set of number is spread out. For the paper purposes, we opted for the measure via the average deviation. The average deviation is equal to the following formula:

$$
\text { average deviation }=\frac{1}{n} \sum_{i=1}^{n}\left(x_{i}-\bar{x}\right)
$$

where:

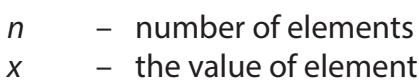

$\bar{x} \quad-$ the mean

This formula expresses an average of the differences between each element of the data set and the mean (Bartsch, 1987). The results will enable defining the level of knowledge and skill differentiation. The results of both surveys were analysed and based on the method of comparison with use of average, the common features were synthetized.

\section{Results and discussion}

Data observed in the given municipalities divided according to the project management knowledge areas defined by the international standards are summarized below and they are interconnected with the basic principle of project management - triple constraint.

Table 1 The structure of respondents (the number of respondents)

\begin{tabular}{|c|c|c|c|c|c|c|c|c|c|}
\hline \multicolumn{2}{|c|}{ Sex } & \multicolumn{9}{c|}{ Age } & \multicolumn{4}{c|}{ Years of practice } \\
\hline male & female & $\begin{array}{c}\mathbf{2 5 - 3 5} \\
\text { years }\end{array}$ & $\begin{array}{c}\mathbf{3 6 - 4 5} \\
\text { years }\end{array}$ & $\begin{array}{c}\mathbf{4 6 - 5 5} \\
\text { years }\end{array}$ & $\begin{array}{c}\mathbf{5 6} \text { years } \\
\text { and more }\end{array}$ & $\begin{array}{c}\text { less than } \mathbf{1} \\
\text { year }\end{array}$ & $\mathbf{1 - 3}$ years & $\mathbf{4 - 7}$ years & $\begin{array}{c}\mathbf{8} \text { years } \\
\text { and more }\end{array}$ \\
\hline 32 & 33 & 16 & 29 & 13 & 7 & 5 & 11 & 33 & 16 \\
\hline
\end{tabular}

Table 2 Questionnaire answers and criteria of their scaling

\begin{tabular}{|c|c|}
\hline Certainly not & - I have no knowledge of the issue and I need complete training and education in the given field \\
\hline Rather not & $\begin{array}{l}\text { - I have heard about the issue, but I have never solved them, I need thorough training and education in the given } \\
\text { field (refreshment problems, definition of the issue, application examples, etc.) }\end{array}$ \\
\hline Rather yes & $\begin{array}{l}\text { - I have studied and solved the issue in the past, but I would not be comfortable with solving it at the moment, I need } \\
\text { to refresh knowledge in the given field }\end{array}$ \\
\hline Certainly yes & $\begin{array}{l}\text { - I have vast knowledge of the issue and I tend to solving it regularly, training is not needed, I am able to work } \\
\text { independently in the given field }\end{array}$ \\
\hline
\end{tabular}


When assessing the results from the triple constraint point of view, it is possible to summarize that the areas with the lowest level of knowledge in the municipalities of the II and III level in South Moravian Region are the areas such as: Project Scope Management, Project Quality Management and Project Communication Management. They all showed more than 40\% of ignorance. These areas include processes such as creation of Work Breakdown Structure (WBS) or defining and validating the project scope, quality assurance and quality control on the basis of the tools such as systematic data collection, histograms, trend analysis, Pareto analysis, cause and effect analysis, etc. or the development of communication plan, preparation and finalization of project documentation and use of project IT software.

The WBS has the greatest impact on planning project scope and, subsequently, planning time and cost (PMI, 2011). Lacking the proper knowledge of this method, project planning and its execution is highly endangered. This knowledge area is mainly connected with planning, executing and controlling of scope, while quality management and methods and techniques used are significantly related to the production process and products themselves. Results in this area prove the validity of survey results even more strongly because there is an assumption that project managers in regional development do not have the necessary skills for quality assessment of production processes and products. Nevertheless, the knowledge of basic principles of quality assessment represents the "must have" knowhow of project managers in any area. The communication knowledge area represents a supportive power for the management of triple constraint attributes. This does not pertain to the management of triple constraint factors as much as to the tools for ensuring of their proper planning and executing. The effective communication with stakeholders represents one of the critical success factors of projects in general and IT support one of the preconditions (not necessarily) for effective project management. It also simplifies the final documentation of projects. According to the collected data, it can be stated that the use of IT technology and preparation of communication plan with stakeholders pose no problems for project managers. Nevertheless, IT
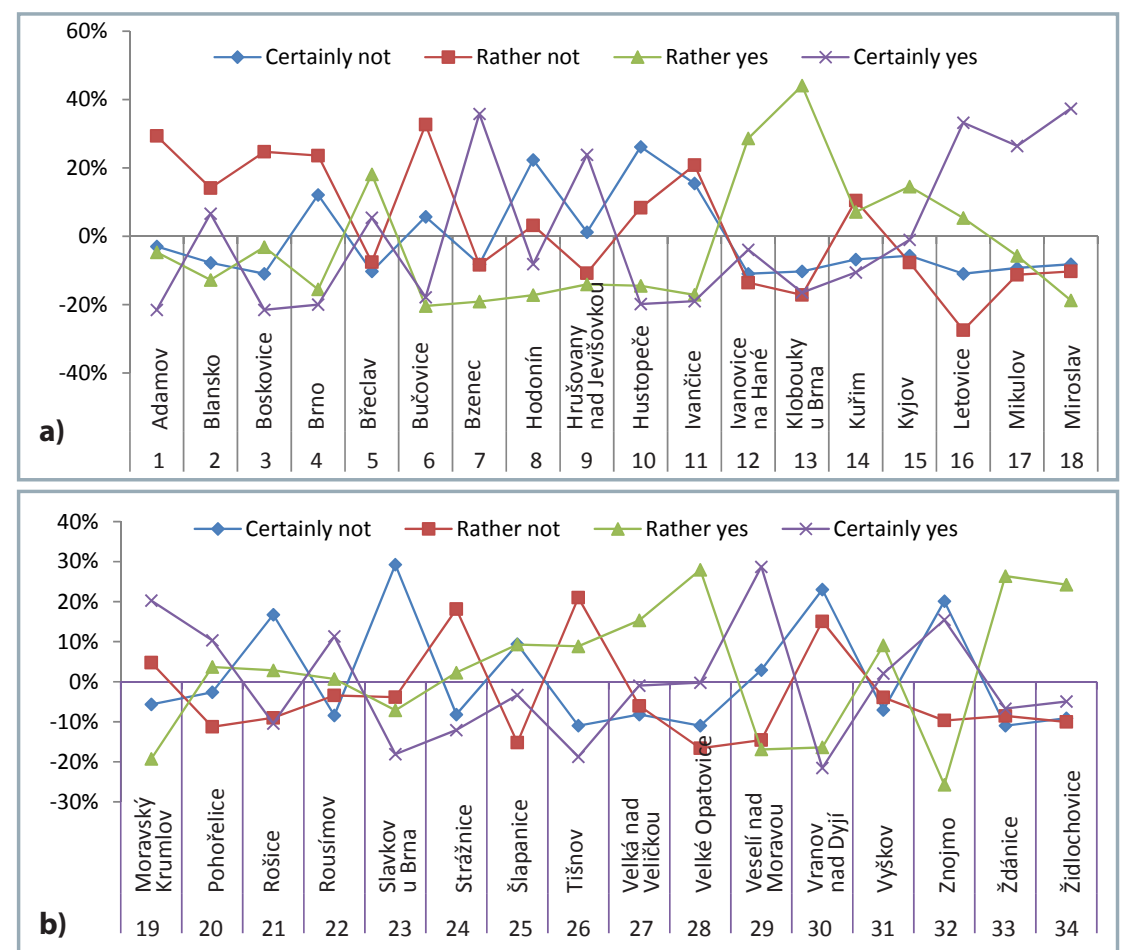

Fig. 1a-b Dispersion of level of knowledge in South Moravian Region in the field of project management (all knowledge areas) Source: authors software utilized as a support of project management is still not a common tool in the observed municipalities.

On the contrary, knowledge areas with the best results (with the highest level of knowledge - over 60\%), are: Integration Management, Cost Management, Change Management and Procurement Management. These knowledge areas include processes such as developing project plan, definition of project objectives and benefits, preparation of project organizational structure and developing of responsibility matrix, budget determination, preparation of cash flow and calculation of profitability data, payback period or net present value, processes connected with the management of changes in project triple constraint or all processes connected with the management of procurements and contractual relationships. In general, there is no problem within these areas; moreover, Project Procurement Management represents the best evaluated knowledge area (approximately $70 \%$ of positive responses). From the triple constraint point of view, this knowledge area represents a supportive power. With a proper knowledge of agreement statement, law conditions and all other contractual issues, many of problems that occur within a project can be quickly and effectively solved.

The results for South Moravian Region are presented in Fig. 1 (a-b). In order to obtain a clear picture, we must look at the situation in the data set of statistical dispersion. It demonstrates how knowledge areas in given municipalities vary from the total average of level of knowledge in South Moravian Region. Fig. 1 ( $a-b)$ introduces the dispersion of level of knowledge in the municipalities of the II and III level from the total average of level of knowledge in South Moravian Region in all knowledge areas of project management. The positive or negative difference from regional average oscillates from approximately $45--30 \%$ on the upper limit and from approximately $1.5--0.5 \%$ on the lower limit. It is obvious that collected data are differentiated around the mean within this range. The mean is expressed by central line $(0.00 \%)$, the values express the spread of 
dispersion. For better understanding, the lines between values are used.

To get a relevant picture about the situation in the area of knowledge and skills in project management, we can compare these results with the results of research conducted on the level NUTS III in the Czech Republic. The data obtained in this research are presented in Fig. 2.

It has been observed that Scope Management, Quality Management and Risk Management were the most problematic knowledge areas with the lowest level of knowledge among project managers working in regional development in all regions. The ignorance of Scope knowledge area reached over $60 \%$; the lack of knowledge of Quality and Risk areas reached around 50\%. These knowledge areas significantly influence the project triple constraint and without proper knowledge of their principles and way of implementation, the projects can hardly be successful.

Fig. 2 introduces the dispersion of knowledge level in the NUTS III regions from the total average of knowledge level in the Czech Republic in all knowledge

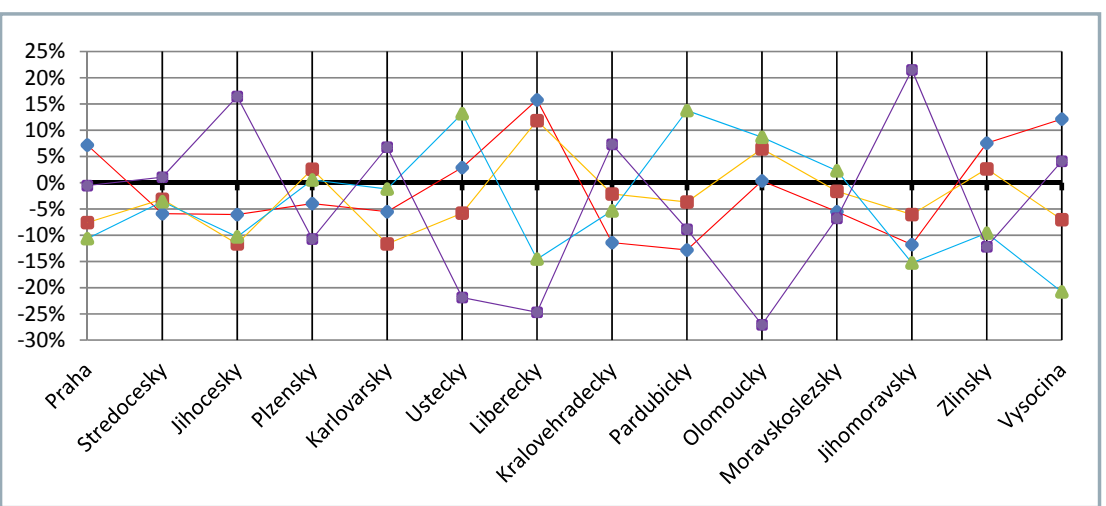

Fig. 2 Dispersion of level of knowledge in the NUTS III regions in the field of project management (all knowledge areas) Source: Kopeckova and Machal, 2016

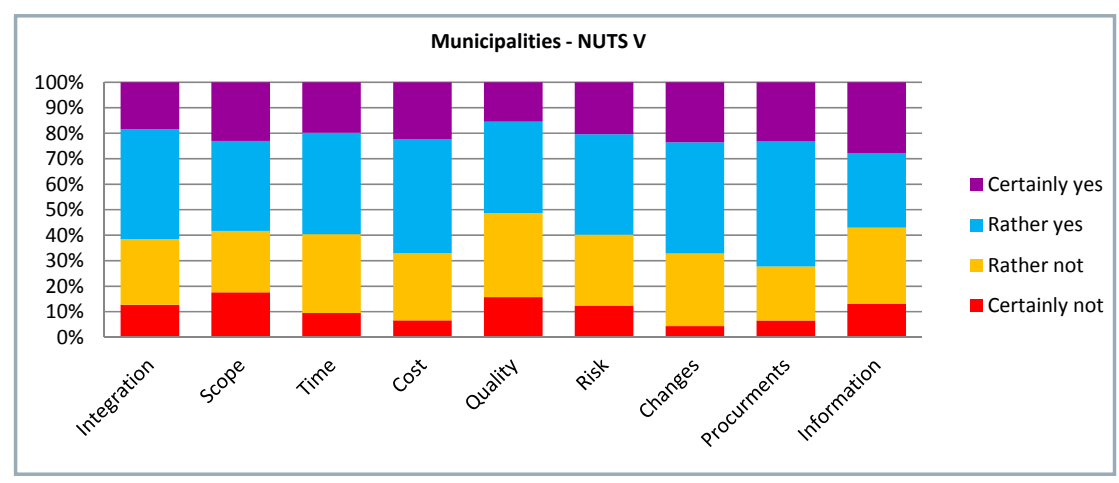

Fig. 3 Average data in knowledge areas in the municipalities of South Moravian Region

Source: authors

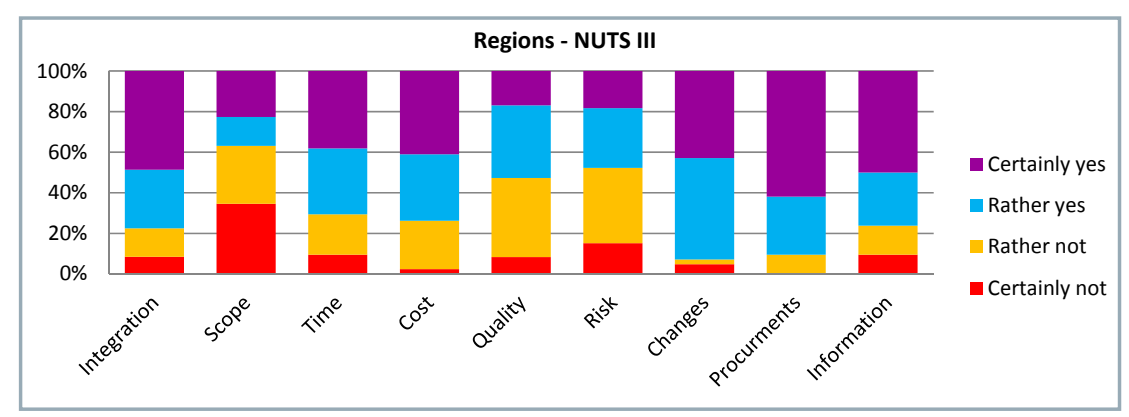

Fig. 4 Average data in knowledge areas in regions in the Czech Republic Source: authors areas of project management. The positive or negative difference from national average oscillates from $20--22 \%$ on the upper limit and from $1--1 \%$ on the lower limit. It is obvious that within this range, the collected data differentiate around the mean.

In order to obtain a better picture of the situation at the level of NUTS III regions and level of NUTS $V$ regions, the following figures are presented.

Fig. 3 shows average data in the given knowledge areas in all the municipalities in South Moravian Region in the Czech Republic. Fig. 4 shows average data in the given knowledge areas in all the regions in the Czech Republic. Average data at both levels of observation (municipalities, regions) enable comparing all data surveyed. The figures show the level of knowledge and skills in the given knowledge areas, where the NUTS $\mathrm{V}$ level shows a higher level of average ignorance of project management knowledge areas. At the NUTS III level, there can be seen a higher level of knowledge and skills than at the NUTS V level. Project Scope Management represents a knowledge area with the highest level of ignorance at both levels of observation, while the level of ignorance within this knowledge area is higher at the NUTSIII level.Theignorance of Scope Management at the NUTS V level is about $40 \%$; it is approximately $60 \%$ at level III. On the contrary, Project Procurement Management represents the best evaluated knowledge area at both levels (the knowledge of Project Change Management is higher by approximately $2 \%$ at the NUTS III level). The average knowledge at the NUTS V level is approximately $70 \%$; it is approximately $90 \%$ at the NUTS III level. On the basis of comparison of average data observed at both levels, we can conclude that the high level of differentiation in the knowledge and skills of project managers exists between the NUTS V and NUTS III levels.

The European Union aims to strengthen the social and economic cohesion of Member States and has spent a huge amount of money to invest in order to boost the social and economic development in the regions. In the programming period 2014-2020, the approved budget for the Czech Republic is $€ 32,082,340,686$ in total, from which the sum $€ 24,203,705,168$ 
comes from the EU budget and the remaining $€ 7,878,635,518$ comes from the national budget (European Commission, 2015). Furthermore, the amount of public procurements in the Czech Republic is of the substantive level. For instance in 2011, the capacity of public procurements was of the level of approximately 229 billion CZK and in 2014, the capacity of public procurement was of the level of approximately 376 billion CZK (MMR, 2016). This data is related only to registered public procurement in the Journal of Public Procurement of the Czech Republic. There is a large amount of money that is not registered in the system. Competent project managers are essential for project success and their personalities, abilities, skills and knowledge play a key role in successful or unsuccessful solving of regional issues.

It is evident from the survey that Scope, Quality and Communication are the areas which are affected by ignorance the most. While Quality and the methods of its control and assurance can be taken as marginal in projects in regional development, the other results - significant ignorance in the Scope and Communication knowledge areas - raise the alarm. The Project Scope Management is about creating of hierarchical structure based on several levels of detailed project activities or output. It is very difficult to prepare project schedule and project budget without the proper output structuring. The underestimation of planning phase may result in huge problems in execution phase and damaging of trust of sponsors.

While Scope ignorance jeopardize all project phases, the ignorance of Communication management endanger the project itself. Without proper communication plan, the relevant stakeholders can be neglected and project success is hardly achievable.

Very interesting phenomenon can be seen in the knowledge area that is perceived as the best evaluated. The highest score was attributed to Project Procurement Management (approximately 70\%) and considering the evaluation of Word Economic Forum, which is preparing the ranking of countries on the basis of Global Competitiveness Index $(\mathrm{GCl})$, it is obvious that there is a relation between the results. The Czech Republic is ranked the $31^{\text {st }}$ country out of 140 countries from over the world, while it is ranked the $57^{\text {th }}$ country in the world in the years 2015-2016 in the $1^{\text {st }}$ pillar: Institution. This pillar evaluates the areas such as the burden of government regulation, wastefulness of government spendings or transparency of government policymaking. Considering the "burden of government regulation" part, the Czech Republic is of the $120^{\text {th }}$ rank (WEF, 2016). The results of the presented survey at the local level can prove the validity of this data in this area. The Czech Republic is highly regulated country with wide range of regulation, and work routine at municipal offices includes mainly the implementation of regulations. This is related to management of finances as well. Project Cost Management is the second best evaluated knowledge area in the presented survey. Even though the levels of our survey (municipalities of the II and III level in South Moravian Region) and of WEF (Czech Republic) are different, the mutual connection and regulation phenomenon within the regions of the Czech Republic can be observed. The Czech officer (project manager dealing with projects at the regional level) is much more familiar with processes of regulation rather than with steps necessary to move tasks forward. This finding is supported by survey results at the level of NUTS III region in the Czech Republic as well (see the results above).

As stated in several studies (Ika et al., 2011 or Silvius and Schipper, 2014), the role of project managers in the field of regional development requires adequate abilities, skills and knowledge. This can influence the project positively or negatively as a whole; therefore, orientation on the level of knowledge of project managers should be in core interest of any decision maker. However, since the decision making is firstly centralized on the national government level, the change of thinking should start at this point. The best tailored education for project managers does not change the system itself. The survey on the abilities and skills of project managers in regional development in South Moravian Region confirms the hypothesis that the level of abilities and skills is highly differentiated in the municipalities of the II and III levels. The positive or negative difference from regional average oscillates from approximately $45--30 \%$ on the upper limit and from approximately $1.5--0.5 \%$ on the lower limit. This paper also demonstrates how the level of knowledge and skills differs between the regions of NUTS III and NUTS V levels. The knowledge of basic project management techniques and principles in NUTS III regions deviate from the mean in the range of $-20 \%-+20 \%$. The numbers related to the NUTS $V$ level show even higher differentiation than at the NUTS III level.

This can be the reason why some of the regions (or municipalities) are more successful in realizing regional projects than others. The impact of the level of knowledge of project managers working in regional development will be a matter of future research.

\section{Conclusion}

The purpose of this paper was to confirm that the level of knowledge and skills of project managers in the field of regional development are of a high differentiation and to identify the knowledge areas that are affected by the ignorance the most in the municipalities of the II and III levels of South Moravian Region in the Czech Republic.

The development of regional policy in the Czech Republic and in the EU in the last decade and solutions of problems of regional development through the EU subsidy policy have caused differences and erroneous perception of the project management concept, projects and effective tools and techniques of project management. These differentiated perceptions result in much differentiated level of knowledge and skills of project managers at regional levels. The surveys on the abilities and skills of project managers in NUTS III regions in the Czech Republic and in NUTS V in South Moravian Region in the Czech Republic prove that the level of knowledge and skills of project managers in the field of regional development is highly differentiated. Balancing and increasing the level of knowledge and skills of project managers should be taken as a goal of decision-making bodies that are responsible for policy making in the Czech Republic. As presented data show, the Czech Republic is highly regulated country, which is also proved by the levels of knowledge and skills of project managers at the regional level. The best evaluated knowledge area is the processing of regulation itself. Next to the intensification of endeavour to increase the level of knowledge and skills of 
project managers in given regions, there should be efforts to decrease the level of regulation in the Czech regions.

The survey results on both regional levels NUTS III and NUTS V have shown that the knowledge area affected by the ignorance at the highest level is mainly Scope Management. Training and focusing interest particularly in this area in all regions should be complying with international standards that are based on long-term monitoring and analysis of best practices of a large number of projects, both at the regional and global level. This should be in interest of all regions because Scope Management represents a basic precondition of successful project planning and executing. Paper findings should serve as input information for the future research tasks in the field or regional development as well.

It is also notable that the number of production companies, which are utilizing agricultural techniques in the field of project management in order to achieve success, is currently growing. Therefore, the knowledge of project standards is vital.

\section{Acknowledgements}

This paper was published with the support of the Internal Grant Agency of Faculty of Regional Development and International Studies No. SP3160821.

\section{References}

ALAM, M. - GALE, A. - BROWN, M. - KHAN, A. I. 2010. The importance of human skills in project management professional development. In International Journal of Managing Projects in Business, vol. 3, no. 3, pp. 495-516.

BANNERMAN, P. L. 2008. Defining project success: a multilevel framework. PMI Research Conference 2008.

BARRATA, A. 2006. The tripple constraint, a tripple illusion. In 2006 PMI Global Congress Proceedings - Seattle, Washington.

BARTSCH, H. J. 1987. Mathematic Equations. SNTL - Nakladatelství technické literatury. Praha. (In Czech: Matematické vzorce).

CUELLAR, M. 2010. Assessing project success. Moving beyond the triple constraint. IRWITPM, Missouri.

EUROPEAN COMMISSION, 2015. European structural and investments funds. Accessible at: https://cohesiondata.ec.europa.eu/countries/CZ FRANK, T. 2002. The superior project manager. Global Competency Standards and Best Practices. Marcel Dekker Inc., New York. ISBN: 0-8247-0639-0.

GAREIS, R. - HUEMANN, M. - MARTINUZZI, A. 2013. Project Management and Sustainable Development Principles. Newtown Square: Project Management Institute, Inc.

HYVÄRI, I. 2006. Success of projects in different organizational conditions. In Project Management Journal, vol. 37, no. 4, pp. 31-41. HWANG, B. G. - NG, W. J. 2013. Project management knowledge and skills for green construction: Overcoming challenges. In International Journal of Project Management, vol. 31, pp. 272-284.

IKA, L. A. - DIALLO, A. - THUILLIER, D. 2011. Critical success factors for World Bank projects: An empirical investigation. In International Journal of Project Management, Elsevier Ltd and IPMA. doi:10.1016/j. ijproman.2011.03.005

IMPLEMENTARY REGULATION 388/2002. Decree of the Ministry of the Interior on the Designation of Administrative Districts of Municipalities with an Auhorized Municipal Office and Administrative Districts of Municipalities with Extended Powers (In Czech: Vyhláška Ministerstva vnitra č. 388/2002 Sb. o stanovení správních obvodů obcí s pověřeným obecním úřadem a správních obvodů obcí s rozšířenou působností ve znění pozdějších předpisů. Sbírka zákonů ČR).

IPMA, 2006. IPMA Competence Baseline for Project Management. Version 3.0. The Netherlands: International Project Management Association.
ISO, 2012. ISO 21500: 2012(E). Guidance on Project Management, International Organization for Standardization.

IYER, S. - KITSON, M. -TOH, B. 2005. Social capital, economic growth and regional development. In Regional Studies, vol. 39, pp. 1015-1040. JÓ, P. - BARRY, M. 2008. The Most Important Success Factors for Implementation Government Projects in Developing Countries. In PICMET '08 Portland International Center for Management of Engineering and Technology. Cape Town, s.n., pp. 1400-1409.

KHAN, R. - SPANG, K. 2011. Critical Success Factors for International Projects. IEEE IDAACS, Prague.

KHANG, D. B. - MOE, T. L. 2008. Success criteria and factors for international development projects: a life-cycle-based framework. In Project Management Journal, vol. 39, no. 1, pp. 229-236.

KOPECKOVA, M. - MACHAL, P. 2016. Survey on the level of knowledge and skills of project managers in regional development. In Acta Universitatis Agriculturae et Silvicultare Mendelianae Brunensis, vol. 64, no. 4, pp. 1325-1335.

LECHLER, T. G. - COHEN, M. 2009. Exploring the role of steering committees in realizing value from project management. In Project Management Journal, vol. 40, pp. 42-54.

MIR, F. A. - PINNINGTON, A. H. 2014. Exploring the value of project management: Linking project management performance and project success. In International Journal of Project Management, vol. 21, no. 5, pp. 209-213.

MMR, 2016. Annual Report on Public Procurement. Accessible at: http://www.portal-vz.cz/cs/Spoluprace-a-vymena-informaci/ Vyrocni-zpravy-a-souhrnne-udaje-o-verejnych-zakazk/ Statisticke-udaje-o-verejnych-zakazkach

NUNNENMACHER, S. 2011. A preliminary survey on subjective measurements and personal insights into factors of perceived future project success. ESEM, Banff, pp. 396-399.

PMI, 2011. Practice Standard for Work Breakdown Structures. $2^{\text {nd }}$ ed. Newtown Square: Project Management Institute, 111 pp. ISBN 978-1-933890-13-5.

PMI, 2013. A Guide to the Project Management Body of Knowledge (PMBOK ${ }^{\circledast}$ guide). $5^{\text {th }}$ ed. Newtown Square: Project Management Institute, 589 pp. ISBN 978-1-935589-67-9.

RODRÍGUEZ-POSE, A. - FRATESI, U. 2004. Between development and social policies: The impact of European structural funds in objective 1 regions. In Regional Studies, vol. 38, pp. 97-113.

SILVIUS, A. J. G. - SCHIPPER, R. P. J. 2014. Sustainability in project management competencies: Analyzing the competence gap of project managers. In Journal of Human Resource and Sustainability Studies, vol. 2, no. 2, pp. 40-58.

SILVIUS, A. J. G. - SCHIPPER, R. P. J. - PLANKO, J. - VAN DEN BRINK, J. - KÖHLER, A. 2012. Sustainability in Project Management. Gower Publishing.

STORPER, M. 2011. Why do regions develop and change? The challenge for geography and economics. In Journal of Economic Geography, vol. 11, pp. 333-346.

THOMAS, J. - MULLALY, M. 2007. Understanding the value of project management: First steps on an international investigation in search of value. In Project Management Journal, vol. 38, pp. 74-89.

TOO, E. G. - WEAVER, P. 2013. The management of project management: A conceptual framework for project governance. In International Journal of Project Management, pp. 1-13.

VAN WYNGAARD, C. J. - PRETORIUS, J. H. C. - PRETORIUS, L. 2012. Theory of the triple constraint - A conceptual review. 2012 IEEE International Conference on Industrial Engineering and Engineering Management.

WINTER, M. - SZCZEPANEK, T. 2008. Projects and programmes as value creation processes: A new perspective and some practical implications. In International Journal of Project Management, vol. 26, pp. 95-103. WEF, 2016. Global Competitiveness Report 2015-2016. Accessible at: http://www3.weforum.org/docs/gcr/2015-2016/Global_ Competitiveness_Report_2015-2016.pdf 